\title{
HIGH LINE TIMELINE
}

1934 Inauguration of the elevated West Side Line, built to replace a mid-nineteenth-century street-level railway and to separate the railway from surface-level traffic.

1960 As a result of decentralization and the increasing market dominance of trucking over freight railways, Saint John's Park Terminal is sold by New York Central Railroad, and the southernmost section of the viaduct is dismantled by the city.

1976 The West Side Line viaduct is bought by the federal government's Consolidated Rail Corporation (Conrail).

1980 Rail service ceases on the West Side Line viaduct.

1983 Conrail begins efforts to divest from the High Line.

Congress passes the National Trails System Act, which leads to the conversion of disused railway rights-of-way to recreational "rails-to-trails" projects.

Architect Steven Holl proposes to construct housing and public space atop the viaduct.

1989 Chelsea Property Owners, a consortium of landowners, files an application with the Interstate Commerce Commission requesting an adverse abandonment order, which would require Conrail to demolish the viaduct and allow them to develop on land beneath the viaduct.

1991 Rockrose Development Corporation demolishes the southern portion of the viaduct to build 265 housing units, leaving the viaduct in its current form, ending on Gansevoort Street in the Meatpacking District. 
1993 Promenade Plantée is completed in Paris, a linear park built above a disused viaduct that served as an inspiration for the creation of the High Line.

1999 CSX Transportation acquires Conrail and works with the Regional Planning Association to strategize on the future use of the viaduct.

Friends of the High Line (FHL) is founded by Joshua David and Robert Hammond after meeting at a community hearing in Chelsea on the future of the former West Side Line viaduct. The designation of the structure as the "High Line" came from a local nickname for the viaduct dating back to the 1980 os.

2001 Photographer Joel Sternfeld completes a visual survey of the landscape atop the High Line, published as a book titled Walking the High Line, which was used to generate support and funding for the FHL.

2002- FHL conducts a study to examine the feasibility of converting 2003 the viaduct into an elevated linear park and opens a design competition for imagining the future of the structure.

2004 As a result of the design competition, FHL and the City of New York select the landscape architecture firm James Corner Field Operations, the architecture and design studio Diller Scofidio + Renfro, and the garden designer Piet Oudolf.

City of New York commits \$50 million to establish the High Line park.

2005 City of New York assumes ownership of the High Line viaduct from CSX.

City approves zoning for the Special West Chelsea District (an area bound by 1oth and 11th Avenues from West 3oth Street to West 16th Street) to release height restrictions, encourage residential and commercial development, and facilitate the reuse of the High Line.

Federal Surface Transportation Board issues a certificate of interim trail use, allowing the city to remove most of the line from the national railway system. 
2006 Groundbreaking begins on the first, southernmost section of the park from Gansevoort Street to West 2oth Street.

2009 Phase 1 completed and opened to the public.

2011 Phase 2, from West 2oth Street to West 3oth Street in West Chelsea, is completed and opened to the public.

CSX Transportation agrees in principle to donate the northernmost section of the viaduct, from 30 th to 34 th Streets, to the city. Related Companies, owner of the development rights to the West Side Rail Yards, agrees not to tear down the 1oth Avenue spur of the elevated railway.

2012 Groundbreaking begins on Hudson Yards, a \$20 billion, twenty-eight-acre mixed-use redevelopment project at the northern tip of the High Line jointly funded by the City of New York, the State of New York, and the Metropolitan Transit Authority, partially over the West Side Rail Yard, to stimulate further development along the Hudson River.

2014 Phase 3 of the High Line, from West 3 oth Street to Hudson Yards at West 34th Street, is completed and opened to the public.

2015 New home of the Whitney Museum of American Art, designed by Renzo Piano, is constructed at the southern tip of the High Line at Gansevoort Street in the Meatpacking District.

Extension of the 7 Subway Line to Hudson Yards opens at 34th Street and 11th Avenue.

201610 Hudson Yards, the first tower completed in the Hudson Yards development, opens in May. The tower is built directly over the High Line, with the pedestrian promenade running through its base.

2017 Projected construction of the Spur, an extension from Phase 3 of the High Line into Hudson Yards. 

DECONSTRUCTING THE HIGH LINE 
